\title{
Language of Witness: Survivor Testimony and Narrative Representation of the Mauthausen Experience
}

\begin{abstract}
This study analyses and compares how survivors of the Nazi concentration camp of Mauthausen (Austria) recount significant events or situations in the camp at specific times and places in their testimonies published, right after the liberation, between 1945 and 1950. As an initial and exploratory stage of a large-scale investigation into survivor narratives, this article highlights two intersecting events at the Mauthausen main camp, Himmler's visits and the arrival of Dutch Jews, and addresses the question of how Gostner, Hoffmann, Schifko-Pungartnik, Stantke, and Wiesenthal in their written accounts assessed, understood, reconstructed, and transmitted similar events, and how these camp experiences shaped their individual social realities. Preliminary answers in this study suggest that a systematic and comprehensive comparison of the inmates' individual perceptions provides a more nuanced understanding of survivors' shared harrowing experiences at the main camp of Mauthausen. Specifically, the study's findings reveal how survivors interpreted their daily social reality as they were profoundly transformed and deeply scarred by the brutal and denigrating processes, hierarchies, and rules at the camp.
\end{abstract}

Keywords: Holocaust, Mauthausen, Nazi concentration camps, survivor accounts

"No one came out as he went in" (Kogon 2005 [1946], 300). This simple but powerful statement by the Holocaust survivor and historian Eugen Kogon, in his publication The Theory and Practice of Hell, expresses the inescapable physical, psychological, and social transformation each prisoner experienced as they endured the Nazi concentration camps. Leaving the "normality" of the outside world for an unknown encapsulated world with brutal and obscure hierarchies, processes, languages, and rules, profoundly changed the inmates and deeply scarred them for the rest of their lives. Unlike many survivor narratives, Kogon's account goes beyond recounting his personal experience in a Nazi camp. Adopting sociological and psychological perspectives, he aims to uncover and understand the internal structures and processes that turned camp life into a daily ordeal of unrelenting physical suffering and personal degradation for the inmates.

My enquiry into narrative survivor testimony about the Mauthausen camp experience derives its impetus from analytical studies by Holocaust survivors such

2 Open Access. (C) 2021 Siegrun Wildner, published by De Gruyter. (c) BY-NC-ND This work is licensed under the Creative Commons Attribution-NonCommercial-NoDerivatives 4.0 International License. 
as Eugen Kogon (2006 [1946]), Elie A. Cohen (1953), Victor Frankl (2014 [1959]), and Benedikt Kautsky (1946). The focal point of these examinations is survivors' experiences as they pass through various stages of their camp existence under the most extreme conditions: from the "stage of initial reaction" upon arrival to the "stage of adaption," and finally, the "stage of resignation," which Cohen interprets as "complete acceptance of life in the camp" $(1953,179)$. The camp experience, of course, is shaped by the survivor's individual social reality, or "unreality" as Hannah Arendt labelled it $(1950,63)$, depicting their unique perceptions and interpretations of a specific event or situation at a specific time and place. If one accepts the obvious premise that "only the man inside knows," as Victor Frankl suggests (2014 [1959], 6), the reader of survivor narratives must attempt to gain insight into survivors' personal perceptions of everyday camp life. For the literary critic, the question arises of how one should approach these texts as objects of study, especially if one wants to go beyond the overt historical dimension and questions of factual veracity. As James E. Young rightly points out in his seminal work Writing and Rewriting the Holocaust, "it is not a matter of whether one set of facts is more veracious than another" $(1988,39)$; it is not about comparing or even "disqualifying competing accounts" (10). Instead, "the critical reader accepts that every Holocaust writer has a 'different story' to tell, not because what happened to so many others was intrinsically 'different', but because how victims and survivors have grasped and related their experiences comprises the actual core of 'their story"' (Young 1988, 38; emphasis in original).

While acknowledging the numerous challenges and limitations involved in analysing survivor narratives, this study attempts "to penetrate to an internal view of the univers concentrationnaire" (Sofksy 1997, 13). ${ }^{1}$ It is not the goal of the present analysis to identify descriptive patterns in survivor narratives, but rather to pursue questions such as how survivors have assessed, understood, and transmitted their experiences in one particular camp, specifically the main camp of

1 In his analysis of power in the camps, Sofsky asks sceptically if it is "even possible to engage in scientific methods to penetrate to an internal view of the univers concentrationnaire" (1997 [1993], 13), and settles for "interpretive depth" (11). Young cautions against using contemporary theory with "its often all-consuming vocabulary" which diverts attention from the historical realities and makes it inaccessible to those outside of the "methodological code" (1988, 3). He also sees challenges in researching survivor narratives due to their reconstructed nature as well as their interpretative consequences. Kranebitter extensively justifies his empirically guided sociological study of factors that contributed to a prisoner's survival chances. One way to deal with survivor accounts empirically, he argues, is to connect quantitative analyses "mit der mikrosoziologischen Analyse sozialer Situationen” [with microsociological analyses of social situations] (Kranebitter 2014, 230; all translations in this article are my own unless otherwise indicated). 
Mauthausen (KLM). ${ }^{2}$ What can their narratives reveal? What is expressed? How is it expressed? What is not expressed? Does each of these narratives lead to a particular interpretation of situations and events? This study will analyse two major events that Mauthausen inmates were able to witness and record in their survivor accounts: (1) Reichsführer-SS (Reich SS Leader) Heinrich Himmler's visits to the camp, events typically viewed only through the historical lens as a simple entry in the records of the SS administration; and (2) the arrival of Dutch Jews in the camp and their brutal treatment by the SS. This enquiry should be viewed as an initial and exploratory stage in a long-term, cross-language comprehensive study of narrative testimonies by Mauthausen survivors that will ultimately provide more complete answers to the questions posed above. Drawing on insights of multiple disciplines (for example sociology, psychology, history, and phenomenology), answers to the questions posed above have the potential to uncover unknown aspects - or to question (or confirm) existing details and nuances - of the survivors' Mauthausen experiences and ensuing representations. The most revealing parts of the primary texts will be those situations or events that intersect or overlap and/or provide a more nuanced understanding of camp life. These survivor narratives must, however, be evaluated in conjunction with other sources to yield the greatest insights.

The large-scale study of survivor testimonies proposed here will involve the Herculean task of establishing an investigative framework with a viable set of criteria that will allow the greatest possible number of written eyewitness accounts to be reviewed through a multidisciplinary lens. Between August 1938 and May 1945, an estimated 197,464 prisoners from over forty different nations passed through the Nazi concentration camp of Mauthausen and its forty-nine satellite camps in Austria. At least 90,000 prisoners died as a result of the extreme and inhumane conditions in these camps; more than 14,000 of them were Jews. ${ }^{3}$ The main camp of the Mauthausen complex was established to supply forced labour for the SS-run Deutsche Erd- und Steinwerke (DEST), a company infamous for its stone quarries. During the course of the war, the importance of granite excavation and construction projects gave way to an emphasis on armament production. The main camp was liberated on 5 May, 1945 by the 11th Armored Division of the US Third Army, at which time about 20,000 prisoners were in the Mauthausen camp (Baumgartner 2006a, 24-25).

2 In this article, the abbreviation "KLM" refers to the Stammlager of the Mauthausen Konzentrationslager (the main camp of the Mauthausen complex).

3 Maršálek (2006, 197, 230). Similar numbers are provided by the KZ-Gedenkstätte Mauthausen (n.d.), “Mauthausen” (n.d.), and Kranebitter (2014, 170). 
In spite of publication difficulties during the immediate post-war years in Germany and Austria, the first eyewitness accounts in German about KLM appeared between 1945 and 1950, for example Meine Erlebnisse im Konzentrationslager Mauthausen by Paul Geier (n.d.); 1000 Tage im KZ by Erwin Gostner (1946); Mauthausen: Sklaven des 20. Jahrhunderts by Otto Hoffmann (1946); Leichenträger ans Tor! by Manfred Schifko-Pungartnik (1946); Mordhausen by Edmund Richard Stantke (n.d.); and KZ. Mauthausen: Bild und Wort by Simon Wiesenthal (1946). ${ }^{5}$ A brief survey of these texts reveals that they vary considerably in format, length, and style. In terms of content, they represent varied realities - that is, each survivor's personal reality as perceived at the time. When post-factum elements were added to the narratives as they were written, the texts also echo the respective survivors' perceptions when trying to reconstruct their memories of their Nazi camp experience.

The inmates' work assignments and social rank among fellow prisoners significantly shaped their perceptions of camp life. For instance, prisoners with a higher social status within the camp, who were so-called prisoner-functionaries, typically had the advantage of becoming "privileged witnesses." This term was coined and explained by the Auschwitz survivor and writer Primo Levi in his collection of essays The Drowned and the Saved as a description of those "who had the ability and luck to attain a privileged observatory without bowing to compromises, and the skill to tell what they saw, suffered, and did with the humility of

\footnotetext{
4 This publication contains two survivor accounts: a more extensive one by Paul Geier (“K.Z.-Häftling 14985”) and a shorter testimony under the heading "Schutzhäftling Nr. 50801" by Karl Breitenfelder. Geier's decision to publish his account under his concentration camp registration number rather than his name can be viewed as a testimonial statement in itself. He probably wanted to stress how the prisoners in the camps were stripped of their personal identities and reduced to mere numbers. In his account, Breitenfelder identifies Paul Geier as the author of the first account in this publication. According to Breitenfelder, he and Geier spent twelve months together in Mauthausen and saw each other on a daily basis.

5 Most of the authors' biographies are difficult to trace, and sometimes the only source of biographical data is the Häftlingskarte, the inmate's official record at Mauthausen, which is not necessarily the most reliable source of information. Data from Häftlingskarten and other documents used for this article were provided by the ITS Digital Archive, Bad Arolsen: Paul Geier: Gestapo Kartei Frankfurt, 1.2.3.6/12190577; KZ Mauthausen, Häftlingspersonalkarten, 1.1.26.3/1455238, 1455239; Befreiungslisten verschiedener Nationalitäten, 1.1.26.1/1304206 - Otto Hoffmann: Häftlings-Personal-Karte Otto Hoffmann 1910, Mauthausen, 1.1.26.3/1489080\#2; Überstellungen von Häftlingen des SS-Arbeitslagers Saurerwerke Wien XI, 1.1.26.1/0189-307/0251/0016, doc. no. 1317330\#1 Manfred Schifko: KZ Dachau, Zugangsbuch, 1.1.6.1/9892997; KZ Dachau, Transportliste, 1.1.6.1/9913130; KZ Mauthausen, Veränderungsmeldung, 1.1.26.1/1308427; KZ Mauthausen, Entlassungen, 1.1.26.1/1284848 - Edmund Stantke: KZ Mauthausen, Häftlingspersonalkarten, 1.1.26.3/1779534, 1779535 .
} 
a good chronicler, taking into account the complexity of the Lager phenomenon and the variety of human destinies being played out in it” $(1989,6)$. Survivor Otto Hoffmann was one of the prisoner-functionaries, or Prominente, as they were called at the Mauthausen camp. In the preface to the second edition of his testimonial account Mauthausen: Sklaven des 20. Jahrhunderts, Hoffmann reveals to his readers: "Ich selbst war auf der 'Politischen Abteilung', der berüchtigten Gestapo-Zentrale, als Häftling tätig. Dort habe ich, dauernd mit einem Bein im Grabe stehend, mehr erlebt und erfahren, als jedes andere Opfer dieser schändlichen Einrichtung des Nazismus" [As an inmate I was assigned to the "Political Department" - the infamous central office of the Gestapo. Constantly living with one foot in the grave, I witnessed more there and had access to more information than other victims of this horrible Nazi institution] (Hoffmann 1946, 7). As a prisoner working in the Political Department, Hoffmann probably saw transcripts of interrogations, orders from the RSHA (Reich Security Main Office) in Berlin, or reports that were sent from the Mauthausen camp administration to the RSHA. Hoffmann points out how the Mauthausen death registers contained falsified information on prisoners' causes of death. For example, deaths in the gas chambers were reported to the prisoners' German and Austrian families as "natürlich Verstorbene" [died of natural causes]. "Tod durch Erhängen” [death by hanging] in the cells of the Mauthausen bunker showed up simply as "Selbstmord" [suicide] in the death registers that were sent to the SS and to the Police Court in Vienna (Hoffmann 1946, 8). ${ }^{6}$

Not only the Prominente had better access to information; so did prisoners assigned to certain work units. For example, Paul Geier states that his vile work assignment to clean the sewers in the camp increased his mobility within the camp and therefore also provided opportunities to make observations: "Ich bin bei dieser Arbeit im ganzen Lager herumgekommen und konnte so viel beobachten" [This kind of work took me all around the camp and I was thus able to observe a great deal] (Geier n.d., 14). Edmund Stantke's work assignment at the camp laundry allowed him to observe and describe in detail the brutal beatings of newly arrived Jewish prisoners by SS guards who routinely "welcomed" these prisoners in this manner in the area directly behind the laundry (Stantke n.d., 27). Other survivors recount a number of different work assignments during their incarcerations at Mauthausen, which similarly afforded them the opportunity to gather information about the structures and processes of everyday camp life in different sections of the main camp and "network" with fellow inmates.

6 Bubser Wildner (2015) provides a detailed literary analysis of Hoffmann’s (1946) poetry. 
When viewed not just in terms of one among several unique survivor perspectives, a specific event in the camp can appear in a multifaceted light that reveals new shades and nuances of the event itself. For example, Edmund Stantke, Erwin Gostner, and Simon Wiesenthal describe Heinrich Himmler's visits to the Mauthausen main camp. These accounts, and similar ones to be analysed in future, will not only contribute to uncovering missing historical information about Himmler's inspections at KLM but, perhaps more importantly, will also yield new insights into the inmates' perspectives on these visits. Stantke, for example, must have witnessed several inspections by high-ranking SS officials such as Heinrich Himmler, August Eigruber (Gauleiter of Upper Austria), and Ernst Kaltenbrunner, Head of the RSHA and later Chief of the Security Police. He describes these events as a recurring experience: the heightened tension during the preparations for the visit, and how the emaciated and sick prisoners were herded together like sheep and locked away in a block. A sign that read "Caution, Typhus!” was posted on the door to deter Himmler and other SS-inspectors from entering the area. Block Two, the Prominenten-Block for prisoner-functionaries who received more food and looked better nourished, was cunningly set up for Himmler's inspection: only the strongest-looking prisoners had been lined up; a sizeable ration of bread and sausage had been put into the inmates' lockers in open view; and lunch consisted of pea soup with the unheard-of addition of bacon. According to Stantke, Himmler commented on the "sufficient quantity of food" and the "delicious" soup. As soon as Himmler had left, the display of food was revealed to be nothing but a farce. Much to the inmates' disappointment, the SS guards forced the prisoners to return all the food to the SS kitchen immediately. Stantke's inclusion of direct speech in the narrative below adds authenticity and authority to his testimonial account:

\footnotetext{
Himmler war kaum aus dem Lager, da ging's im Block zwei rund. Die Gummiknüppel sausten nur so durch die Luft. "Was", schrie die SS-Mannschaft, "wollt ihr das Brot und die Wurst sofort zurücktragen. Die Kessel mit den Erbsen sind auch noch hier!” Trotz der ernsten Lage haben wir doch noch lachen müssen. Der ganze Proviant war nämlich zum Schein hingestellt. Alles von der SS-Küche. Gern hätten wir das Brot, die Wurst und die Erbsen mit Speck gegessen! Wäre die SS-Mannschaft nicht gleich gekommen, hätten wir wirklich alles verzehrt - die Folgen hätten uns nicht abgehalten. Aber so haben sie uns überrumpelt, sie kannten uns zu genau. (Stantke n.d., 20)
}

[As soon as Himmler had left the camp, Block Two erupted into pandemonium. The SS rubber truncheons had a heyday. The SS squadron yelled, "Take the bread and the sausage back to the kitchen. The cauldron with peas goes back to the kitchen too!" In spite of the seriousness of the situation, we had to laugh. The display of the entire food supply had been nothing but a sham. Everything had 
originated from the SS kitchen. Oh, how we craved the bread, the sausage, and the peas with bacon! Had the SS squadron not shown up right away, we would have eaten everything without worrying about the consequences. But they had completely surprised us; they knew us too well.]

It is not clear from Stantke's account when exactly Himmler's visit took place, but it can be roughly situated between Stantke's arrival at Mauthausen on 11 April 1941 and his transfer to the Gusen camp on 8 April 1944. If Stantke's experiences are recounted in chronological order, Himmler's visit could well have been one of his officially recorded visits in $1941 .^{7}$ While Stantke's account of Himmler's visit may provide some new information, it also raises a number of questions. How did Stantke know about these details? Was he one of the prisoner-functionaries in Block Two? Why did the SS personnel feel the need to perform this charade? Had they been selling prisoners' food supplies on the black market for their own profit and had they, as a result, wanted to cover up their illegal actions? Perhaps future studies of eyewitness accounts not yet examined will help shed light on these issues and contribute to a more detailed and comprehensive view of life at KLM during 1941.

Another report of Himmler's visit to the Mauthausen main camp is given by Erwin Gostner in 1000 Tage im KZ. He remembers Himmler's visit as taking place “an einem Augusttag” [on a day in August] (Gostner 1946, 133). He notes that, in anticipation of the high-ranking visitor, the prisoners had to clean the camp thoroughly. Like Stantke, Gostner reports a heightened level of tension at the camp. Gostner worked in the SS kitchen at that time and, according to his own account, he and his friend Fabro were able to observe the welcoming ceremony for Himmler, which occurred right outside the SS kitchen. In fact, both Gostner and Fabro made a conscious effort to watch and bear witness to this event:

Fabro und ich machen uns an den Mülleimern zu schaffen; wir wollen etwas sehen! Ich stehe an der Rückwand der Tribüne und kann Himmler genau betrachten. [...] Auch Ziereis und Bachmayer sind dabei. Es ist Mittagszeit. Die Arbeitskommandos rücken ins Lager; sie müssen an der Tribüne vorüber. Mit zynischem Lächeln betrachtet Himmler die Elendsgestalten. Dies ist eine Parade besonderer Art! Die Häftlinge heben die müden Köpfe nicht um einen Zoll höher, es ist ihnen völlig gleichgültig, daß dort der Reichsführer SS steht. Wichtig ist nur der Gedanke an die kostbare Ruhe der Mittagszeit und an das Essen, für alles andere haben sie keinen Sinn. (Gostner 1946, 134)

7 After his report of Himmler's visit, Stantke describes the arrival of the first female prisoners at Mauthausen as well as the conversion of Block One into a brothel in June 1942. See Baumgartner (2006b, 92). 
[Fabro and I are fiddling with the garbage cans; we want to watch what's going on! I'm standing by the wall behind the seating area. From there I'm able to watch Himmler closely. [...] Ziereis and Bachmayer are also present. It's lunchtime. The work units are returning to the camp; they have to pass the stand. Himmler is watching these skeletons of misery with a cynical smile on his face. This is a parade of a special kind! The inmates don't lift their tired heads an inch; they are completely indifferent to the presence of the Reichsführer-SS. Their only concern is the precious lunch hour and the chance it offers to get some rest and food; nothing else matters to them.]

Gostner also astutely observes the power structure and hierarchy at play among the Nazis. In vivid language he describes Himmler pacing back and forth on the makeshift podium "wie bei einem Raubtier" [like a predatory animal], exuding an aura of "gefährliche Kühle" [dangerous coldness], with "einem zynischem Lächeln" [a cynical smile] on this face as he watched these "Elendsgestalten" [skeletons of misery] walk by (Gostner 1946, 134). The SS personnel are described as alert and ready to jump to attention to fulfil any order "ihres mächtigen Gebieters" [of their almighty master] (134). In contrast to the SS, the prisoners marching past Himmler do not participate in this display of obsequious behaviour. They simply ignore him. Gostner emphasizes the prisoners' tiredness, their indifference, and their only focus being the thought of food and precious resting time during the lunch hour; everything else was of little account. However, the prisoners of the last work unit, the Strafkompanie (penal company), who return from their back-breaking labour in the stone quarries, do, in fact, muster enough energy to display their hatred for Himmler, as Gostner recounts:

\footnotetext{
Es sind fast lauter Juden, die mit einem Transport aus Holland ins Lager kamen. Sie tragen jeder einen schweren Stein. Aus ihren Augen schießen Strahlen magnetischen Hasses. Himmlers Gestalt strafft sich, das zynische Lächeln um seinen Mund vergeht in einer starren, grausamen Maske. Mit schneidendem Ton wendet sich der Reichsführer SS. zum Lagerkommandanten: “Ziereis, warum leben noch so viele Juden vom Holland-Transport?" [...] Himmlers Wunsch wurde nach seiner Abreise prompt erfüllt. Die gesamte Strafkompanie ging in wenigen Wochen im Steinbruch zugrunde. (Gostner 1946, 134-135)
}

[These men are almost all Jews who had arrived in the camp on a transport from Holland. Each of them is carrying a heavy granite rock. Daggers of hatred shoot from their eyes. Himmler straightens up, the cynical smile on his face freezes into a cruel mask. In a piercing voice the Reichsführer-SS turns to the camp commander: "Ziereis, why are so many Jews from the Holland transport still alive?” [...] Himmler's wish was fulfilled promptly right after his departure. Within a few weeks the entire Jewish work unit had met its end in the stone quarry.] 
Gostner's report provides insight into the Nazi perpetrators' behaviour in such situations: their unabashed display of power and perceived racial superiority, their cynicism and arbitrary actions, as well as their acceptance of the hierarchy among themselves. ${ }^{8}$

How does Himmler's visit and his order to execute this group of Dutch Jews fit into established historical contexts? According to Gostner, Himmler visited the Mauthausen camp in August. Since the first Dutch Jews arrived at KLM in May 1941 and Gostner was released from Mauthausen in December 1941, Himmler's visit must have taken place in 1941. However, historical sources do not confirm such a large number of Dutch Jews at the camp at any one time during that year. Maršálek reports the arrival of approximately 900 Dutch Jews (out of 1,600 Jewish prisoners) in at least three different transports in $1941 .{ }^{9}$

Mauthausen survivor Manfred Schifko-Pungartnik was at the main camp at the same time as Gostner. In his account, Leichenträger ans Tor, he also reports the undocumented arrival and killing of seven thousand Jews from the Netherlands within eight days: "die 7000 'Stück' [waren] in acht Tagen 'weg”" [the 7,000 “items" (were) "gone” within eight days] (Schifko-Pungartnik 1946, 21). His report details camp commandant Franz Ziereis's sardonic and sinister methods of accelerating the mass killings. In the end, SS guards forced large numbers of the Dutch Jews to leap from the edge of a hundred-foot cliff into the stone quarry. After the "Fallschirmspringen" [parachute jumps], as the Nazis cynically termed this method of killing, the remaining Jews had to carry the corpses up the 186 steps of the infamous "Todesstiege" [stairs of death] to the main entrance of the camp. "Leichenträger" [corpse carriers] were then called to the entrance gate to pick up the dead bodies and take them to the camp crematorium.

Similarly to Gostner's account, Schifko-Pungartnik's report of the mass killings of Jews from the Netherlands raises more questions than it answers. None of the historical sources shows the arrival of seven thousand Dutch Jews at KLM. Schifko-Pungartnik notes that the Mauthausen crematorium could not handle the large quantity of “'Aufträge”” [“orders”] (Schifko-Pungartnik 1946, 22) and that additional killings had to be halted for a short while. His wording also seems to suggest that a second oven was installed in the crematorium to keep up with

8 Gostner's second account of a visit by Himmler refers to a particularly gruesome incident: inmates are carrying an injured Jewish fellow prisoner on a stretcher to the infirmary when Himmler orders the young man to be taken to the crematorium instead (1946, 145).

9 Maršálek (2006, 194). According to Maršálek, Jews from the Netherlands arrived in 1941 as follows: "etwas weniger als 50" [a bit fewer than 50] Dutch Jews on 12 or 13 May; 291 prisoners on 25 June; between 260 and 400 prisoners in September and October. The historian Michel Fabréguet $(2002,197)$ estimates there were a total of 2,000 Jews at Mauthausen between 1940 and 1942. 
the number of corpses at that time. Reference to a second oven is also made by the historian Michel Fabréguet, who indicates it was installed in the Mauthausen crematorium in spring 1942, at a time when Mauthausen had already been turned into a slaughterhouse for human beings (2002, 204, 202).

Like Gostner and Schifko-Pungartnik, Simon Wiesenthal describes in his Mauthausen testimony his observations of the brutal killings of Dutch Jews. Wiesenthal's testimony consists of his own drawings of distinct scenes in the camp accompanied by short commentaries. One of these images depicts SS guards who are shoving two prisoners off the hundred-foot cliff into the stone quarry while a large group of fellow prisoners are forced to watch at gunpoint. Wiesenthal states that on 31 March 1943 all these prisoners, "1000 holländische Juden” [1,000 Dutch Jews], were killed the same way. Heinrich Himmler was watching this gruesome scene (Wiesenthal 1946, 46).

As with the other survivor testimonies discussed here, I have not been able to verify Wiesenthal's information against existing historical sources. Perz reports four official visits of Himmler to Mauthausen, two in spring 1941, the third on 16 October 1942, and the fourth on 2 June $1944 .{ }^{10}$ An entry in Himmler's official Dienstkalender [Appointment Book] for 1941 and 1942, which reveals his day-to-day appointments with bureaucrats, SS generals, and foreign leaders, documents one of these "spring visits" to Mauthausen as well as a guided tour with SS-Gruppenführer Pohl on 31 May 1941 (Dienstkalender 1999, 165). Himmler's Dienstkalender does not show a visit in April 1941. However, it is conceivable that he went to Mauthausen on 23 April 1941 during his one-week stay in Austria (Graz, Bruck an der Mur, St. Lambrecht) from 21 April to 27 April. The entry for 23 April 1941 reads: "RFSS fährt zu einer Besichtigung. Gegen 20 Uhr zurück nach Bruck" [Reichsführer-SS went to an inspection, returning to Bruck about 8 p.m.] (Dienstkalender 1999, 153). This visit may have been Himmler's second visit in spring 1941 as recorded by Perz $(2013,12)$. Photographic sources also document Himmler's visit(s) to Mauthausen in April, but do not show a specific date. For example, the digital photo archive of the Bundesarchiv Koblenz contains over seventy photos depicting Himmler at Mauthausen; all but five of these were probably taken in April 1941. ${ }^{11}$ The Bretstein Album includes ten photos that document Himmler's inspection at Mauthausen in April 1941 (Matyus 2014, 116).

10 Perz $(2013,12)$. According to Perz, the activity report in the Mauthausen Tätigkeitsbericht (1 October 1941-28 December 1944) only documents Himmler’s visit on 2 June 1944.

11 Search for “Himmler Mauthausen 1941," performed at https://www.bild.bundesarchiv.de (13 July 2018). 
Unfortunately, a number of pages are missing from Himmler's Dienstkalender. For example, there are no pages for 21-26 August 1941 and 28-30 August 1941 inclusive (Dienstkalender 1999, 198), which makes it impossible to cross-check Gostner's account of Himmler's apparent visit in August 1941. ${ }^{12}$ Additionally, official SS records do not show one thousand Jewish prisoners at KDM in 1943. Maršálek refers to detailed SS statistics of registered Jewish prisoners starting in March 1943, which technically should include Wiesenthal's death count of one thousand Dutch Jews. However, SS records only show a death count of two Jewish prisoners during the entire month of March 1943 (Maršálek 2006, 193-195).

How should one interpret the disparities between survivor eyewitness accounts and historical sources mostly based on SS records? First, the survivors' accounts possibly provide new historical information about Himmler's visits to Mauthausen in August 1941 and March 1943. Considering all sources, including survivor Josef Jira's account of Himmler's inspection at Mauthausen in January $1945,{ }^{13}$ seven or eight official visits are indicated, rather than four (as historiographical sources suggest). Second, the survivors' reports of unregistered transports of Dutch Jews in 1941, 1942, and 1943 challenge existing estimates of Jewish victims at Mauthausen as documented in Maršálek (2006).

Dates and numbers constitute traditional historical facts and provide the necessary sequencing of events as part of a larger chronological framework; in this study, however, the inmates' respective experiences as they watched the situations and events unfold take centre stage. As such, the study follows Victor Frankl's credo that "facts will be significant only as far as they are part of a man's experiences” (Frankl 2014 [1959], 5). For example, when Schifko-Pungartnik recounts "Ein Transport Juden ist eingetroffen. Für uns bedeutet das vorübergehend Ruhe" [A transport with Jews has arrived. To us this means temporary calm and quiet] (Schifko-Pungartnik 1946, 21), the author's facts, assessment, and interpretation converge. Schifko-Pungartnik quickly realized that the SS would shift its attention away from his (most likely non-Jewish) work unit to the newly arrived transport of Jews. The latter would then be the targets of SS beatings and torture while he and his fellow inmates would get a short-lived respite. Schifko-Pungartnik uses the perspective of an "experienced" inmate who is familiar with this "routine."

12 According to the Deutsches Historisches Institut Moskau, Himmler's Dienstkalender from 1943 to 1945 was discovered in 2013 in a Russian Defence Ministry archive in Podolsk and is currently being prepared for publication along with the Dienstkalender from 1937 to 1938 (see "Dienstkalender" n.d.).

13 Jira, in Lettner $(2000,68)$. In his article on orchestras made up of prisoners at KLM, Kurt Lettner mentions Josef Jira’s account of Himmler's visit to KLM in January 1945. 
While he feels a moment of relief, he also expresses deep feelings of empathy for the newly arrived prisoners in the following section of his report.

The way the writer has grasped and related his experience provides a snapshot of the internal view of the inmates' relentless struggle to overcome the deprivations and degradations of the camps. Accounts like those by Erwin Gostner, Otto Hoffmann, Manfred Schifko-Pungartnik, Edmund Richard Stantke, Simon Wiesenthal, and others, in spite of their subjectivity, their reconstructed nature, and their lack of evidential corroboration, remain the primary sources for any effort to get a better grasp of everyday camp life; or, as Young puts it: "The fictiveness in testimony does not involve disputes about facts, but the inevitable variance in perceiving and representing these facts, witness by witness, language by language, culture by culture" $(1988,32)$. As the results of this preliminary study indicate, a systematic and comprehensive cross-reading of survivor narratives promises to provide a more nuanced understanding of the inmates' individual social realities as well as the hierarchies, processes, rules, and brutal treatment at the Mauthausen camp that profoundly transformed and deeply scarred each human being for life, for "no one came out as he went in."

\section{Works cited}

Arendt, Hannah. "Social Science Techniques and the Study of Concentration Camps." Jewish Social Studies 12.1 (1950): 49-64.

Baumgartner, Andreas. Die Befreiung des KZ Mauthausen. Vienna: Verlag des Österreichischen Gewerkschaftsbundes, 2006 .

Baumgartner, Andreas. Die vergessenen Frauen von Mauthausen. Vienna: Mauthausen Komitee Österreich, 2006b.

Bubser Wildner, Siegrun. "Hybrid Testimony and Moral Indictment: A Survivor's Poetic Response to the Mauthausen Nazi Concentration Camp Experience." Holocaust and Genocide Studies 29.3 (2015): 460-477.

Cohen, Elie Aron. Human Behavior in the Concentration Camp. New York: Norton, 1953.

Der Dienstkalender Heinrich Himmlers 1941-42. Ed. Peter Witte, Michael Wildt, Martina Voigt, Dieter Pohl, Peter Klein, Christian Gerlach, Christoph Dieckmann, and Andrej Angrick. Hamburg: Hans Christians Verlag, 1999. Hamburger Beiträge zur Sozial- und Zeitgeschichte: Quellen 3.

“Der Dienstkalender Heinrich Himmlers 1943-1945, 1937-1938.” Deutsches Historisches Institut Moskau, n.d. https://www.dhi-moskau.org/de/forschung/herrschaft-und-krieg/ der-dienstkalender-heinrich-himmlers.html (17 July 2018).

Fabréguet, Michel. "Entwicklung und Veränderung der Funktionen des Konzentrationslagers Mauthausen 1938-1945.” Die nationalsozialistischen Konzentrationslager: Entwicklung und Struktur. Vol. 1. Ed. Ulrich Herbert, Karin Orth, and Christoph Dieckmann. Frankfurt am Main: Fischer TB Verlag, 2002. 193-215. 
Frankl, Viktor. Man's Search for Meaning. 1959. Trans. Helen Pisano. Boston: Beacon Press, 2014.

Geier, Paul [K.Z. Häftling 14985]. Meine Erlebnisse im Konzentrationslager Mauthausen. Baden-Baden: Koelblin, n.d.

Gostner, Erwin. 1000 Tage im KZ: Ein Erlebnisbericht aus den Konzentrationslagern Dachau, Mauthausen, und Gusen. Mannheim: Burger, 1946.

Hoffmann, Otto. Mauthausen - Sklaven des 20. Jahrhunderts: Gedichte und Tatsachenberichte. 2nd ed. Innsbruck: Wagner'sche Universitätsbuchdruckerei, 1946.

Kautsky, Benedikt. Teufel und Verdammte: Erfahrungen und Erkenntnisse aus sieben Jahren in deutschen Konzentrationslagern. Zurich: Büchergilde Gutenberg, 1946.

Kogon, Eugen. The Theory and Practice of Hell. 1946. Trans. Heinz Norden. New York: Farrar, Straus and Giroux, 2006.

Kranebitter, Andreas. Zahlen als Zeugen: Soziologische Analysen zur Häftlingsgesellschaft des KZ Mauthausen. Vienna: new academic press, 2014. Mauthausen-Studien 9.

KZ-Gedenkstätte Mauthausen. Website. n.d. https://www.mauthausen-memorial.org/ (13 July 2018).

Lettner, Kurt. "Musik zwischen Leben und Tod: Musik im Konzentrationslager Mauthausen und seinen Nebenlagern 1939-1945." Oberösterreichische Heimatblätter 54.1-2 (2000): $55-72$.

Levi, Primo. The Drowned and the Saved. Trans. Raymond Rosenthal. London: Abacus, 1989.

Maršálek, Hans. Die Geschichte des Konzentrationslagers Mauthausen: Dokumentation. 4th ed. Vienna: Mauthausen Komitee Österreich, 2006.

Matyus, Stephan. “Auszeit vom KZ-Alltag: Das Bretstein-Album.” Täter: Österreichische Akteure im Nationalsozialismus. Ed. Christine Schindler. Vienna: Dokumentationsarchiv des österreichischen Widerstandes, 2014.107-133. http://www.doew.at/cms/download/ a1837/jb2014_matyus.pdf (13 July 2018).

“Mauthausen.” Holocaust Encyclopedia. United States Holocaust Memorial Museum, n.d. https://www.ushmm.org/wlc/en/article.php?Moduleld=10005196 (13 July 2018).

Perz, Bertrand. Verwaltete Gewalt: Der Tätigkeitsbericht des Verwaltungsführers im Konzentrationslager Mauthausen 1941 bis 1944. Vienna: Bundesministerium für Inneres, 2013. Mauthausen Studien 8.

Schifko-Pungartnik, Manfred. Leichenträger ans Tor! Bericht aus fünfJahren Konzentrationslager. Graz: Moser, 1946.

Sofsky, Wolfgang. The Order of Terror: The Concentration Camp. 1993. Trans. William Templer. Princeton: Princeton University Press, 1997.

Stantke, Edmund Richard. Mordhausen: Augenzeugen-Bericht über Mauthausen. Munich: Gross, n.d.

Young, James E. Writing and Rewriting the Holocaust: Narrative Consequences of Interpretation. Bloomington: Indiana University Press, 1988.

Wiesenthal, Simon. KZ. Mauthausen: Bild und Wort. Linz and Vienna: Ibis, 1946.

Siegrun Wildner is professor at the University of Northern Iowa, USA. Her main areas of research and teaching are Holocaust and genocide studies, intercultural studies, and twentieth-century European literature. 
